\title{
Fatty Acid Pattern and Alkaloids of Echium Rauwolfii
}

\author{
Abdelaziz M. Dawidar \\ Chemistry Department \\ Faculty of Science \\ Mansoura University \\ Egypt
}

\author{
Eman H. Tawfik \\ Chemistry Department \\ Faculty of Science \\ Mansoura University \\ Egypt
}

\author{
Abdul-Sattar H. A Ghani \\ Chemistry Department \\ Faculty of Science \\ Mansoura University \\ Egypt
}
Mamdouh Abdel-Mogib
Chemistry Department
Faculty of Science
Mansoura University
Egypt

\author{
Maha M. Alshamy \\ Botany Department \\ Faculty of Science \\ Mansoura University \\ Egypt
}

\begin{abstract}
The GC/MS analysis of hexane extract revealed the presence of palmitic acid as saturated fatty acid (1.05\%), versus oleic acid $(2.18 \%)$, linoleic acid (1.13\%), cis-8,11,14-eicosatrienoic acid $(2.12 \%)$ as unsaturated fatty acids. On the other hand, $\mathrm{CH}_{2} \mathrm{Cl}_{2}$ extract contained palmitic acid methyl ester (3.55\%), and methyl isostearate (1.17\%) as saturated fatty acids, versus linoleic acid methyl ester $(3.57 \%)$ and linolenic acid methyl ester $(10.01 \%)$ as unsaturated fatty acids. The GC/MS analysis of the alkaloid-rich fraction indicated the presence of the pyrazolidine alkaloids petranine (2.97\%), 7-angeloyl-9-(2-methylbutyryl) retronecine (4.22\%), 7 angeloylretronecine $(0.59 \%)$ and 9-angeloylretronecine $(0.47 \%)$.
\end{abstract}

The butanol extract showed the heights DPPH radical scavenging activity $\left(\mathrm{IC}_{50}=14.3 \mu \mathrm{g}\right)$,. while ethyl acetate extract was very weak in activity $\left(\mathrm{IC}_{50}=432.3 \mu \mathrm{g}\right.$ ) and no activity with hexane and methylene chloride extract.

The antimicrobial potentials of E. rauwolfii extracts were examined. The inhibition of the fungi species by ethyl acetate extract exert was comparable to Amphotericin B. The inhibition zone of the butanol extract against Streptococcus pneumonia was comparable to Ampicillin, against Pseudomonas aeruginosa was comparable to Gentamicin and Escherichia coli was comparable to Gentamicin.

The cytotoxicity against HePG-2 of ethyl acetate extract and butanol extract were "very strong", and that of hexane extract and methylene chloride extract were "moderate", against MCF-7 of ethyl acetate extract and butanol extract were "strong", that of methylene chloride extract was "moderate", and that of hexane extract was "weak" and against HCT-116 of butanol extract was "very strong", of ethyl acetate extract was "strong", of methylene chloride extract and hexane extract were "moderate".

Keywords: fatty acids, pyrrolizidine alkaloids, Echium rauwolfii, Boraginaceae

\section{INTRODUCTION}

Echium rauwolfii Delile (Boraginaceae) is an erect or ascending hispid-setose annual winter herb with branched stems [1]. About 40 species of Echium are known that are mainly distributed in the Mediterranean region, Western Asia and Southern Europe [2,3]. The genus is represented by about 7 species in Egypt, including E. rauwolfii [1].

Echium seeds contain specialty oil; it has many potential uses in the pharmaceutical industry for treatment of eczema, acne, and other skin disorders and in the cosmetic and personal care products industry. Echium oil is applied topically to reduce skin wrinkles and protects and moisturizes the skin from sun exposure [4]. As a chemical class, pyrrolizidine alkaloids are some of the leading plant-based toxins associated with harmful effects in both humans and animals $[5,6]$. However, the antioxidant, antimicrobial and anti cancer (Hep-G2, HCT116 and MCF-7) activities, that we will introduce here, do not confirm this situation, so that, we have interested here to introduce the results of inspection of both the fatty acid and the pyrrolizidine alkaloid patterns.

\section{EXPERMINTAL}

\section{$2.1 \mathrm{GC} / \mathrm{MS}$}

The GC/MS analysis was performed at Agriculture Research Center, National Research Center (NRC), Dokki, Cairo, Egypt, using a Thermo Scientific, Trace GC Ultra / ISQ Single Quadrupole MS, TG-5MS fused silica capillary column $(30 \mathrm{~m}, 0.251 \mathrm{~mm}, 0.1 \mathrm{~mm}$ film thickness). For GC/MS detection, an electron ionization system with ionization energy of $70 \mathrm{ev}$ was used, Helium gas was used as the carrier gas at a constant flow rate of $1 \mathrm{~mL} / \mathrm{min}$. The 
injector and MS transfer line temperature was set at $280^{\circ} \mathrm{C}$. The oven temperature was programmed at an initial temperature $40^{\circ} \mathrm{C}$ (hold $3 \mathrm{~min}$ ) to $280^{\circ} \mathrm{C}$ as a final temperature at an increasing rate of $5^{\circ} \mathrm{C} / \mathrm{min}$ (hold $5 \mathrm{~min}$ ). The quantification of all the identified components was investigated using a percent relative peak area. A tentative identification of the compounds was performed based on the comparison of their relative retention time and mass spectra with those of the NIST, WILLY library data of the GC/MS system.

\subsection{Solvents}

Hexane $\left(60-80^{\circ} \mathrm{C}\right)$ was obtained from Alpha Chemika; methylene chloride was obtained from SDFCL sd fine-chem limited; ethyl acetate, methanol, butanol and acetone were obtained from Adowic.

\subsection{Cell lines}

Hepatocellular carcinoma HePG-2, mammary gland breast cancer MCF-7 and colorectal carcinoma HCT-116. The cell lines were obtained from ATCC via Holding company for biological products and vaccines (VACSERA), Cairo, Egypt.

\subsection{Chemical reagents}

The reagents RPMI-1640 medium, MTT, DMSO and 5fluorouracil (sigma co., St. Louis, USA), Fetal Bovine serum (GIBCO, UK). 5-fluorouracil was used as a standard anticancer drug for comparison.

\subsection{Plant material}

Echium rauwolfii Delile was collected in March 2014 at Hibis Temple from arable land-side of cultivation in EL Kharga Oasis which, Western Desert, Egypt. It was identified by the $4^{\text {th }}$ author according to $[1,7]$ and $[8]$. A herbarium specimen was deposited in the Herbarium of Botany Department, Faculty of Science, Cairo University.

\subsection{Processing of plant material}

The collected plant material was dried in shade and grinded at room temperature to give $(181.760 \mathrm{~g})$ of dried powder material. The plant material was extracted by soxhlet extractor with hexane, followed by methylene chloride, then ethyl acetate, and finally butanol to give extracts (5.780, 2.200, $1.49,58.21 \mathrm{~g}$, respectively).

A sample of hexane extract was analyzed using GC/MS technique to give: 1-hexadecanol (Rt $31.09 \mathrm{~min}, 2.26 \%$ ), 1octadecanol (Rt $36.51 \mathrm{~min}, 4.18 \%)$, nonadecane $\left(\mathrm{R}_{\mathrm{t}} 39.18\right.$ $\min , 0.91 \%)$, 1-eicosanol ( $\left.R_{t} 41.43 \mathrm{~min}, 3.27 \%\right)$, eicosane $\left(R_{t}\right.$ $41.57 \mathrm{~min}, 1.15 \%)$, palmitic acid $\left(\mathrm{R}_{\mathrm{t}} 45.67 \mathrm{~min}, 1.05 \%\right)$, oleic acid $\left(\mathrm{R}_{\mathrm{t}} 45.93 \mathrm{~min}, 2.18 \%\right)$, linoleic acid $\left(\mathrm{R}_{\mathrm{t}} 48.16 \mathrm{~min}\right.$, $1.13 \%$ ), cis-8,11,14-eicosatrienoic acid ( $\mathrm{R}_{\mathrm{t}} 48.32 \mathrm{~min}$, $2.12 \%$ ), pentacosane ( $\left.\mathrm{R}_{\mathrm{t}} 52.12 \mathrm{~min}, 2.70 \%\right)$, heptacosane ( $\mathrm{R}_{\mathrm{t}}$ $55.79 \mathrm{~min}, 1.81 \%)$, nonacosane $\left(\mathrm{R}_{\mathrm{t}} 59.21 \mathrm{~min}, 1.96 \%\right)$, nonacosanol ( $\left.\mathrm{R}_{\mathrm{t}} 61.12 \mathrm{~min}, 1.19 \%\right)$, hentriacontane $\left(\mathrm{R}_{\mathrm{t}} 62.42\right.$ $\min , 2.97 \%$ ).

A sample of $\mathrm{CH}_{2} \mathrm{Cl}_{2}$ extract was analyzed by GC/MS technique to give: hexadecane ( $\mathrm{R}_{\mathrm{t}} 31.29 \mathrm{~min}, 1.31 \%$ ), octadecane ( $\left.\mathrm{R}_{\mathrm{t}} 36.68 \mathrm{~min}, 0.94 \%\right)$, palmitic acid methyl ester ( $R_{t} 39.91 \mathrm{~min}, 3.55 \%$ ), eicosane ( $R_{t} 41.57 \mathrm{~min}, 0.60 \%$ ), linoleic acid methyl ester ( $\left.\mathrm{R}_{\mathrm{t}} 43.82 \mathrm{~min}, 3.57 \%\right)$, linolenic acid methyl ester ( $R_{t} 43.97$ min, 10.01\%), methyl isostearate
$\left(\mathrm{R}_{\mathrm{t}} 44.54 \mathrm{~min}, 1.17 \%\right)$, docosane $\left(\mathrm{R}_{\mathrm{t}} 46.04 \mathrm{~min}, 0.45 \%\right)$, tetracosane ( $\left.\mathrm{R}_{\mathrm{t}} 50.16 \mathrm{~min}, 0.47 \%\right)$, pentacosane ( $\mathrm{R}_{\mathrm{t}} 52.09 \mathrm{~min}$, $0.86 \%)$, hexacosane $\left(\mathrm{R}_{\mathrm{t}} 53.97 \mathrm{~min}, 0.90 \%\right)$, heptacosane $\left(\mathrm{R}_{\mathrm{t}}\right.$ $55.77 \mathrm{~min}, 0.72 \%)$.

A sample of plant material (135.000 g) was soaked in methanol (1L) for $24 \mathrm{~h}$ filtered, and the filtrate was evaporated to $1 / 4$ the initial volume. The extract was diluted with water and acidified with hydrochloric acid, then extracted by $\mathrm{CH}_{2} \mathrm{Cl}_{2}$. The aqueous acidic layer was basified to $\mathrm{pH} 9$ by adding ammonium hydroxide and then extracted again by $\mathrm{CH}_{2} \mathrm{Cl}_{2}$ to give the alkaloid-rich fraction $(22.610 \mathrm{~g})$. A sample from the alkaloid-rich fraction gave by GC/MS: trans 3-pinanone ( $R_{t} 19.80 \mathrm{~min}, 3.90 \%$ ), petranine ( $\mathrm{R}_{\mathrm{t}} 21.12$ $\min , 2.97 \%)$, endobornyl acetate $\left(R_{t} 23.78 \mathrm{~min}, 1.90 \%\right)$, 7angeloyl-9-(2-methylbutyryl)retronecine $\quad\left(R_{t} 27.50 \quad \mathrm{~min}\right.$, 4.22\%), 7-angeloylretronecine ( $\left.\mathrm{R}_{\mathrm{t}} 28.22 \mathrm{~min}, 0.59 \%\right)$, 9angeloylretronecine $\quad\left(\mathrm{R}_{\mathrm{t}} \quad 29.28 \quad \mathrm{~min}, \quad 0.47 \%\right), \quad 14-$ methylpentadecanoic acid methyl ester $\left(\mathrm{R}_{\mathrm{t}} 42.26 \mathrm{~min}, 0.40 \%\right)$, eicosane ( $\left.R_{t} 43.98 \mathrm{~min}, 0.58 \%\right)$, heneicosane $\left(R_{t} 46.30 \mathrm{~min}\right.$, $0.87 \%$ ), docosane ( $\left.\mathrm{R}_{\mathrm{t}} 48.52 \mathrm{~min}, 1.50 \%\right)$, tricosane ( $\mathrm{R}_{\mathrm{t}} 50.66$ $\min , 2.42 \%)$, hexanedioic acid, dioctyl ester $\left(\mathrm{R}_{\mathrm{t}} 52.72 \mathrm{~min}\right.$, $24.04 \%$ ), pentacosane ( $R_{t} 54.68 \mathrm{~min}, 4.48 \%$ ), hexacosane $\left(R_{t}\right.$ $56.57 \mathrm{~min}, 4.16 \%)$, heptacosane $\left(\mathrm{R}_{\mathrm{t}} 58.41 \mathrm{~min}, 2.75 \%\right)$, octacosane ( $\left.\mathrm{R}_{\mathrm{t}} 60.17 \mathrm{~min}, 1.69 \%\right)$.

\subsection{Evalution of biological activity of the plant extracts}

\subsubsection{Antioxidant activity}

The antioxidant activity of extract was determined at the Regional Center for Mycology and Biotechnology (RCMB) at Al- Azhar University by the DPPH free radical scavenging assay in triplicate and average values were considered. Freshly prepared $(0.004 \% \mathrm{w} / \mathrm{v})$ methanol solution of 2,2diphenyl-1-picrylhydrazyl (DPPH) radical was prepared and stored at $10^{\circ} \mathrm{C}$ in the dark. A methanol solution of the test compound was prepared. A $40 \mathrm{ml}$ aliquot of the methanol solution was added to $3 \mathrm{ml}$ of DPPH solution. Absorbance measurements were recorded immediately with a UV-visible spectrophotometer (Milton Roy, Spectronic 1201). The decrease in absorbance at $515 \mathrm{~nm}$ was determined continuously, with data being recorded at $1 \mathrm{~min}$ intervals until the absorbance stabilized (16 $\mathrm{min}$ ). The absorbance of the DPPH radical without antioxidant (control) and the reference compound ascorbic acid were also measured. All the determinations were performed in three replicates and 
averaged. The percentage inhibition (PI) of the DPPH radical was calculated according to the formula:

$$
\mathrm{PI}=[\{(A C-A \mathrm{~T}) / A C\} \times 100] .
$$

Where $A \mathrm{C}=$ Absorbance of the control at $\mathrm{t}=0 \mathrm{~min}$ and $A \mathrm{~T}=$ absorbance of the sample $+\mathrm{DPPH}$ at $\mathrm{t}=16 \mathrm{~min}[9]$.

\subsubsection{Antimicrobial activity assessment}

Extracts were individually tested against a panel of Gram positive (Staphylococcus aureus), Gram negative bacteria (Escherichia coli) and fungi (Candida albicans). Each of the extracts was dissolved in DMSO (1 mg / $\mathrm{ml})$. Whitman filter paper discs were cut with standard size $(5 \mathrm{~mm})$ and sterilized in an autoclave. The paper discs were soaked in the desired concentration of the extracts and placed aseptically in the Petri dishes containing nutrient agar media (agar $20 \mathrm{~g}+$ beef extract $3 \mathrm{~g}+$ peptone $5 \mathrm{~g}$ ) and seeded with Staphylococcus aureus, Escherichia coli and Candida albicans. The Petri dishes were incubated at $36^{\circ} \mathrm{C}$ and the inhibition zones were recorded after $24 \mathrm{~h}$ of incubation. Each treatment was replicated three times. The antibacterial activity of a common standard antibiotic Ampicillin, Gentamicin and antifungal Amphotericin B was also recorded using the same procedure as above at the same concentration and solvents. The \% activity index for the extract was calculated by the formula:

$\%$ Activity Index $=\frac{\text { Zone of inhibition of test extract }(\text { diametre })}{\text { Zone of inhibition by standard }(\text { diametre }) \times 100}$

\subsubsection{Cytotoxicity MTT assay $[10,11]$}

The cell lines HePG-2, MCF-7 and HCT-116 were used to determine the inhibitory effects of extracts on cell growth using the MTT assay. This colorimetric assay is based on the conversion of the yellow tetrazolium bromide (MTT) to a purple formazan derivative by mitochondrial succinate dehydrogenase in viable cells. The cells were cultured in RPMI-1640 medium with $10 \%$ fetal bovine serum. Antibiotics added were 100 units $/ \mathrm{ml}$ penicillin and $100 \mu \mathrm{g} / \mathrm{ml}$ streptomycin at $37 \mathrm{oC}$ in a $5 \% \mathrm{CO}_{2}$ incubator. The cells were seeded in a 96-well plate at a density of $1.0 \times 104$ cells/well [12]. At $37 \mathrm{oC}$ for $48 \mathrm{~h}$ under $5 \% \mathrm{CO}$. After incubation the cells were treated with different concentrations of extracts and incubated for $24 \mathrm{~h}$. After $24 \mathrm{~h}$ of treatment, $20 \mu \mathrm{l}$ of MTT solution at $5 \mathrm{mg} / \mathrm{ml}$ was added and incubated for $4 \mathrm{~h}$. Dimethyl sulfoxide (DMSO) in volume of $100 \mu \mathrm{l}$ is added into each well to dissolve the purple formazan formed. The colorimetric assay is measured and recorded at absorbance of $570 \mathrm{~nm}$ using a plate reader (EXL 800). The relative cell viability in percentage was calculated as (A570 of treated samples/A570 of untreated sample) X 100.

\section{RESULT AND DISCUSSION 3.1 Fatty acid and alkaloid pattern}

Many Echium species are characterized by the presence of polyunsaturated fatty acids [13]. The GC/MS analysis of the volatile fractions (hexane extract and methylene chloride extract) revealed the presence of palmitic acid as saturated fatty acid $(1.05 \%)$, versus oleic acid $(2.18 \%)$, linoleic acid (1.13\%), cis-8, 11, 14-eicosatrienoic acid (2.12\%) as unsaturated fatty acids in the hexane extract. On the other hand, the GC/MS analysis of $\mathrm{CH}_{2} \mathrm{Cl}_{2}$ extract gave palmitic acid methyl ester (3.55\%) and methyl isostearate $(1.17 \%)$ as saturated fatty acids, versus linoleic acid methyl ester (3.57\%) and linolenic acid methyl ester $(10.01 \%)$ as unsaturated fatty acids.

The GC/MS analysis of the alkaloid-rich fraction indicated the presence of the pyrazolidine alkaloids petranine 1 (2.97\%), 7angeloyl-9-(2-methylbutyryl) retronecine 2 (4.22\%), 7angeloylretronecine $3(0.59 \%)$ and 9-angeloylretronecine 4 $(0.47 \%) . \quad 1$ and 4 was identified previously from Echium glomeratum [14], 2 and 3 was identified previously from Echium rauwolfii and horridum [15]. The structures as the following figures:

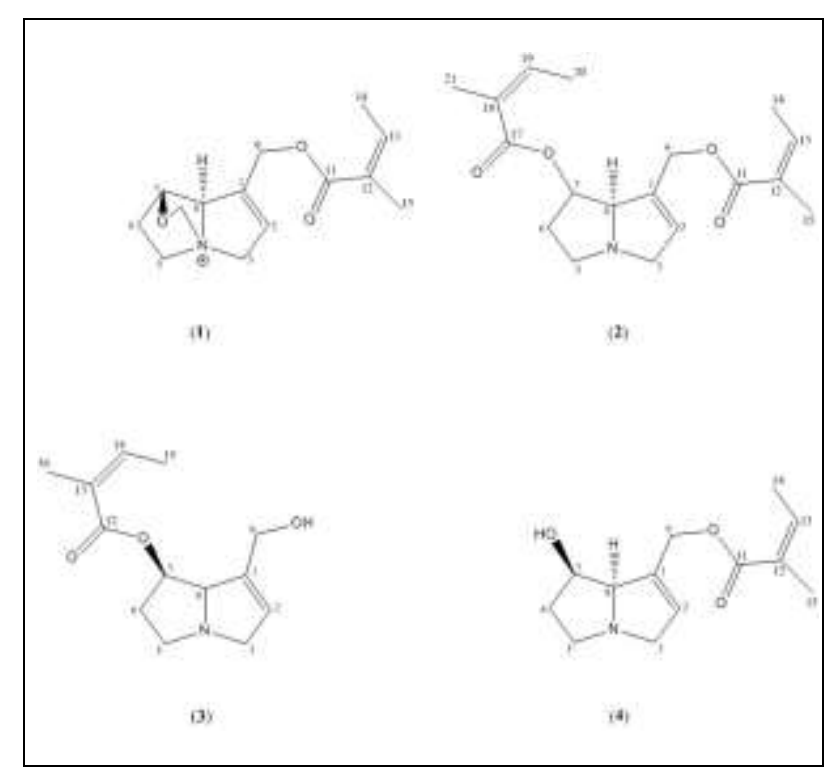

\subsection{Antioxidant activity evaluation}

The free radical of 2, 2-diphenyl-1-picrylhydrazyl (DPPH) is used for detection of the antioxidant activity of the extracts [8]. The butanol extract showed the heights scavenging activity $\left(\mathrm{IC}_{50}=14.3 \mu \mathrm{g}\right.$, Table 1 ), while ethyl acetate extract was very weak in activity $\left(\mathrm{IC}_{50}=432.3 \mu \mathrm{g}\right.$, Table 1$)$ and no activity with hexane and methylene chloride extract when tasted at concentration ranged from (10-5000 $\mu \mathrm{g} / \mathrm{ml})$. 
Table 1: DPPH radical scavenging activity (IC $50 \mu \mathrm{g} / \mathrm{ml}$ )

\begin{tabular}{|c|c|}
\hline Sample code & $\begin{array}{c}\text { DPPH radical } \\
\text { scavenging activity } \\
\left(\text { IC }_{\mathbf{5 0}} \boldsymbol{\mu} \mathbf{g} / \mathbf{m l}\right)\end{array}$ \\
\hline Hexane extract, Er1 & - ve \\
\hline Methylene chloride extract, Er2 & -ve \\
\hline Ethyle acetate extract, Er3 & 432.3 \\
\hline Butanol extract, Er4 & 14.3 \\
\hline Ascorbic acid & 14.2 \\
\hline
\end{tabular}

-ve: no activity even when tasted at concentration ranged from (10- $5000 \mu \mathrm{g} / \mathrm{ml}$ ).

\subsection{Antimicrobial activity assessment}

The antimicrobial potentials of E. rauwolfii extracts were examined by the disc diffusion assay method, using eight pathogenic microbial species; Aspergillus fumigates, Syncephalastrum racemosum, Geotricum candidum, Candida albicans, represent pathogenic fungal species. Streptococcus pneumonia, Bacillis subtillis, represents Gram positive bacteria, Pseudomonas aeruginosa, Escherichia coli, represent Gram negative bacteria. The data were presented in Table 2. The results showed that there were remarkable inhibitions of the microbial growth against the tested extracts. The inhibition zones of ethyl acetate extract (Er3) against the fungi species were comparable to Amphotericin B. The inhibition zone against the Gram-positive bacteria Streptococcus pneumonia of the butanol extract (Er4) was comparable to Ampicillin. The inhibition zones of the butanol extract (Er4) against the Gram-negative bacteria Pseudomonas aeruginosa were comparable to Gentamicin. The inhibition zones of the ethyl acetate extract (Er3) and the butanol extract (Er4) against the Gram-negative bacteria Escherichia coli were comparable to Gentamicin.

\subsection{Cytotoxicity assessment}

Table 3 indicated the relative viability of cells (\%) and table 4 indicated the in-vitro cytotoxicity IC50 $(\mu \mathrm{g} / \mathrm{ml})$. The cytotoxicity against HePG-2 of ethyl acetate extract (Er3) and butanol extract (Er4) were "very strong", and that of hexane extract (Er1) and methylene chloride extract (Er2) were "moderate", against MCF-7 of ethyl acetate extract (Er3) and butanol extract (Er4) were "strong", that of methylene chloride extract (Er2) was "moderate", and that of hexane extract (Er1) was "weak" and against HCT-116 of butanol extract (Er4) was "very strong", of ethyl acetate extract (Er3) was "strong", of methylene chloride extract (Er2) and hexane extract (Er1) were "moderate".
Table 2: The inhibition zone in mm of extracts of $E$. rauwolfii compared to standard antibiotics.

\begin{tabular}{|c|c|c|c|c|c|}
\hline $\begin{array}{l}\text { Tested } \\
\text { microorganism }\end{array}$ & 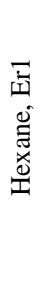 & 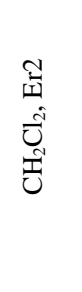 & 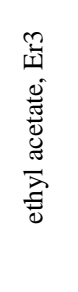 & 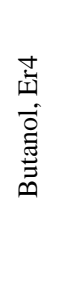 & $\begin{array}{l}\text { Standard } \\
\text { antibiotic }\end{array}$ \\
\hline Fungi & & & & & $\begin{array}{c}\text { Amphotericin } \\
\text { B }\end{array}$ \\
\hline $\begin{array}{c}\text { Aspergillus fumigate } \\
\text { (RCMB 02568) }\end{array}$ & $\begin{array}{l}\mathrm{N} \\
\mathrm{A}\end{array}$ & NA & $\begin{array}{r}19.2 \\
\pm 0.72\end{array}$ & NA & $23.7 \pm 0.1$ \\
\hline $\begin{array}{l}\text { Syncephalastrum } \\
\text { racemosum } \\
(\mathrm{RCMB} 05922)\end{array}$ & $\begin{array}{l}\mathrm{N} \\
\mathrm{A}\end{array}$ & NA & $\begin{array}{r}18.3 \\
\pm 0.58\end{array}$ & NA & $19.7 \pm 0.2$ \\
\hline $\begin{array}{c}\text { Geotricum } \\
\text { candidum } \\
\text { (RCMB 05097) }\end{array}$ & $\begin{array}{l}\mathrm{N} \\
\mathrm{A}\end{array}$ & NA & $\begin{array}{c}21.6 \\
\pm 0.63\end{array}$ & NA & $28.7 \pm 0.2$ \\
\hline $\begin{array}{l}\text { Candida albicans } \\
\text { (RCMB 05036) }\end{array}$ & $\begin{array}{l}\mathrm{N} \\
\mathrm{A}\end{array}$ & NA & $\begin{array}{r}20.2 \\
\pm 1.2\end{array}$ & NA & $25.4 \pm 0.1$ \\
\hline $\begin{array}{c}\text { Gram positive } \\
\text { bacteria }\end{array}$ & & & & & Ampicillin \\
\hline $\begin{array}{c}\text { Streptococcus } \\
\text { pneumonia } \\
\text { (RCMB 010010) }\end{array}$ & $\begin{array}{l}\mathrm{N} \\
\mathrm{A}\end{array}$ & $\begin{array}{c}16.3 \\
\pm 0.58\end{array}$ & $\begin{array}{r}18.6 \\
\pm 0.63\end{array}$ & $\begin{array}{c}20.3 \\
\pm 0.58\end{array}$ & $23.8 \pm 0.2$ \\
\hline $\begin{array}{l}\text { Bacillis subtillis } \\
\text { (RCMB 010067) }\end{array}$ & $\begin{array}{l}\mathrm{N} \\
\mathrm{A}\end{array}$ & $\begin{array}{l}17.6 \\
\pm 1.2\end{array}$ & $\begin{array}{r}21.6 \\
\pm 1.2\end{array}$ & $\begin{array}{l}23.4 \\
\pm 1.2\end{array}$ & $32.4 \pm 0.3$ \\
\hline $\begin{array}{c}\text { Gram negative } \\
\text { bacteria }\end{array}$ & & & & & Gentamicin \\
\hline $\begin{array}{c}\text { Pseudomonas } \\
\text { aeruginosa } \\
\text { (RCMB 010043) }\end{array}$ & $\begin{array}{l}\mathrm{N} \\
\mathrm{A}\end{array}$ & $\begin{array}{l}15.2 \\
\pm 1.2\end{array}$ & $\begin{array}{l}16.8 \\
\pm 1.2\end{array}$ & $\begin{array}{c}18.2 \\
\pm 0.72\end{array}$ & $20.6 \pm 0.58$ \\
\hline $\begin{array}{l}\text { Escherichia coli } \\
\text { (RCMB 010052) }\end{array}$ & $\begin{array}{l}\mathrm{N} \\
\mathrm{A}\end{array}$ & $\begin{array}{c}13.7 \\
\pm 0.72\end{array}$ & $\begin{array}{r}19.2 \\
\pm 0.58\end{array}$ & $\begin{array}{c}20.6 \\
\pm 0.58\end{array}$ & $19.9 \pm 0.3$ \\
\hline
\end{tabular}

NA: No activity. 
Table 3: Relative viability of cells (\%) of $E$. rauwolfii extracts against human tumor cell lines HePG-2, MCF-7 and HCT-116

\begin{tabular}{|c|c|c|c|}
\hline Concentration & HePG-2 & MCF-7 & HCT-116 \\
\hline \multicolumn{4}{|c|}{$5-\mathrm{FU}$} \\
\hline $100 \mu \mathrm{g} / \mathrm{ml}$ & 8.6 & 7.9 & 7.4 \\
\hline $50 \mu \mathrm{g} / \mathrm{ml}$ & 17.1 & 14.8 & 12.1 \\
\hline $25 \mu \mathrm{g} / \mathrm{ml}$ & 24.0 & 21.0 & 19.8 \\
\hline $12.5 \mu \mathrm{g} / \mathrm{ml}$ & 33.1 & 34.5 & 31.4 \\
\hline $6.25 \mu \mathrm{g} / \mathrm{ml}$ & 56.8 & 47.3 & 49.9 \\
\hline $3.125 \mu \mathrm{g} / \mathrm{ml}$ & 70.6 & 58.2 & 60.5 \\
\hline $1.56 \mu \mathrm{g} / \mathrm{ml}$ & 88.7 & 76.0 & 73.6 \\
\hline \multicolumn{4}{|c|}{ Hexane extract, Er1 } \\
\hline $100 \mu \mathrm{g} / \mathrm{ml}$ & 31.7 & 44.1 & 34.0 \\
\hline $50 \mu \mathrm{g} / \mathrm{ml}$ & 42.6 & 56.3 & 45.2 \\
\hline $25 \mu \mathrm{g} / \mathrm{ml}$ & 55.3 & 67.5 & 57.6 \\
\hline $12.5 \mu \mathrm{g} / \mathrm{ml}$ & 68.2 & 78.6 & 69.8 \\
\hline $6.25 \mu \mathrm{g} / \mathrm{ml}$ & 87.4 & 95.2 & 93.9 \\
\hline $3.125 \mu \mathrm{g} / \mathrm{ml}$ & 100 & 100 & 100 \\
\hline $1.56 \mu \mathrm{g} / \mathrm{ml}$ & 100 & 100 & 100 \\
\hline \multicolumn{4}{|c|}{ Methylene chloride extract, Er2 } \\
\hline $100 \mu \mathrm{g} / \mathrm{ml}$ & 24.5 & 33.7 & 20.8 \\
\hline $50 \mu \mathrm{g} / \mathrm{ml}$ & 35.4 & 45.1 & 27.4 \\
\hline $25 \mu \mathrm{g} / \mathrm{ml}$ & 46.8 & 58.6 & 38.5 \\
\hline $12.5 \mu \mathrm{g} / \mathrm{ml}$ & 57.2 & 69.3 & 52.3 \\
\hline $6.25 \mu \mathrm{g} / \mathrm{ml}$ & 71.7 & 90.5 & 73.6 \\
\hline $3.125 \mu \mathrm{g} / \mathrm{ml}$ & 92.6 & 100 & 91.2 \\
\hline $1.56 \mu \mathrm{g} / \mathrm{ml}$ & 100 & 100 & 100 \\
\hline \multicolumn{4}{|c|}{ Ethyl acetate extract, Er3 } \\
\hline $100 \mu \mathrm{g} / \mathrm{ml}$ & 9.3 & 17.6 & 13.4 \\
\hline $50 \mu \mathrm{g} / \mathrm{ml}$ & 17.2 & 25.0 & 20.2 \\
\hline $25 \mu \mathrm{g} / \mathrm{ml}$ & 24.7 & 33.5 & 27.1 \\
\hline $12.5 \mu \mathrm{g} / \mathrm{ml}$ & 36.4 & 45.3 & 38.7 \\
\hline $6.25 \mu \mathrm{g} / \mathrm{ml}$ & 55.1 & 70.7 & 67.9 \\
\hline $3.125 \mu \mathrm{g} / \mathrm{ml}$ & 73.8 & 86.1 & 75.6 \\
\hline $1.56 \mu \mathrm{g} / \mathrm{ml}$ & 95.6 & 100 & 96.5 \\
\hline \multicolumn{4}{|c|}{ Butanol extract, Er4 } \\
\hline $100 \mu \mathrm{g} / \mathrm{ml}$ & 8.0 & 18.8 & 8.8 \\
\hline $50 \mu \mathrm{g} / \mathrm{ml}$ & 15.8 & 26.3 & 15.9 \\
\hline $25 \mu \mathrm{g} / \mathrm{ml}$ & 23.4 & 35.7 & 24.7 \\
\hline $12.5 \mu \mathrm{g} / \mathrm{ml}$ & 31.9 & 47.2 & 35.2 \\
\hline $6.25 \mu \mathrm{g} / \mathrm{ml}$ & 54.6 & 68.9 & 58.1 \\
\hline $3.125 \mu \mathrm{g} / \mathrm{ml}$ & 67.1 & 89.4 & 74.0 \\
\hline $1.56 \mu \mathrm{g} / \mathrm{ml}$ & 85.3 & 100 & 92.3 \\
\hline
\end{tabular}

Table 4: Cytotoxicity assessment of $E$. rauwolfii extracts against human tumor cell lines HePG-2, MCF-7 and HCT116

\begin{tabular}{|c|c|c|c|}
\hline \multirow{2}{*}{ Extract } & \multicolumn{3}{|c|}{ In vitro Cytotoxicity IC50 $(\mu \mathrm{g} / \mathrm{ml})^{*}$} \\
\cline { 2 - 4 } & HePG-2 & MCF-7 & HCT-116 \\
\hline 5-FU* & $7.9 \pm 0.25$ & $5.4 \pm 0.18$ & $5.3 \pm 0.33$ \\
\hline Hexane, Er1 & $36.4 \pm 2.81$ & $67.3 \pm 3.73$ & $41.2 \pm 2.64$ \\
\hline $\begin{array}{c}\text { Methylene } \\
\text { chloride, Er2 }\end{array}$ & $22.9 \pm 1.34$ & $40.9 \pm 3.12$ & $17.6 \pm 1.35$ \\
\hline Ethyl acetate, Er3 & $8.6 \pm 0.36$ & $14.2 \pm 0.97$ & $10.7 \pm 1.10$ \\
\hline Butanol, Er4 & $7.1 \pm 0.30$ & $15.1 \pm 1.06$ & $8.5 \pm 0.78$ \\
\hline
\end{tabular}

IC50 $(\mu \mathrm{g} / \mathrm{ml}) *: 1-10$ (very strong). $11-20$ (strong). $21-50$ (moderate). $51-100$ (weak) and above 100 (non-cytotoxic); 5-FU* $=5$-fluorouracil, a standard cytotoxic.

\section{ACKNOWLEDGMENTS}

I would like to thank Ministry of Science and Technology in Iraq for funding my M.Sc. study and Chemistry Department, Faculty of Science, Mansoura University, for providing some research facilities.

\section{REFERENCES}

1. Täckholm, V. 1974. Students Flora of Egypt, Cairo University, Cooperative Printing Co. Beirut. $2^{\text {nd }}$. Ed; pp. 450-451.

2. Feinbrun-Dothane, N. 1978. Flora Palaestina, The Israel Academy of sciences and Humanities. Vol. 3, pp. 74-77.

3. Jafri, S. M. H. and El-Gadi, A.1979. Flora of Libya, Al Faateh University, Tripoli. Vol. 68, pp. 33-49.

4. Nicholls, P.,2000.Viper's bugloss and related species Echium spp. John King \& Sons Ltd. www.dweckdata.com/Published_papers/Echium.pdf

5. Schmeller T., El-Shazly A., Wink M., 1979 Allelochemical activities of pyrrolizidine alkaloids: interactions with neuroreceptors and acetylcholine related enzymes. J. Chem. Ecol. 23, 399-416.

6. Stegelmeier B.L., Edgar J.A., Colegate S.M., Gardner D.R., Schoch T.K., Coulombe R.A. and Molyneux R.J. 1999. Pyrrolizidine alkaloid plants, metabolism and toxicity. J. Nat. Toxins 8, 95-116.

7. Boulos L. 2000. Flora of Egypt. Al Hadara Publishing, Cairo, Egypt. Volume 2 pp. 303,302.

8. Boulos L. 2009. Flora of Egypt (Checklist). Revised annotated addition, Al Hadara Publishing, Cairo, Egypt. pp.190.

9. Yen G.C. and Duh P.D. 1994. Scavenging effect of methanolic extracts of peanut hulls on free radical and active oxygen species, J Agric Food Chem, 42: 629-632.

10. Mosmann T. 1983. Immunol. J. Methods 65, 55-63. 
11. Denizot F. 1986. Lang. R.; Immunol. J. Methods 22, 271-277.

12. MauceriHJ, HannaNN, BeckettMA, GorskiDH, StabaMJ, StellatoKA, BigelowK, Heimann R, Gately S, Dhanabal M, SoffGA, Sukhatme VP, Kufe DW, Weichselbaum RR Nature 1998. Combined effects of agiostatin and ionizing radiation in antitumour therapy. 394:287-291.

13. Sakineh Abbaszadeh S., Radjabian T., Taghizadeh M., Fazeli F. and Salmaki Y. September 2011. Characterization of fatty acids in different organs of some Iranian Echium plants. Vol. 5(19), pp. 48144821, 23.

14. Alali F.Q., Tahboub, Y.R., Ibrahim, E.S., Qandil, A., Tawaha, K., Burgess, J.P, Sy, A., Nakanishi, Y., Kroll, D.J., Oberlies, N.H. 2008. Pyrrolizidine alkaloids from Echium glomeratum (Boraginaceae). Phytochemistry. 69, 2341-2346.

15. El-Shazly A., Abdel-All M., Tei, A., Wink, M. 1999. Pyrrolizidine alkaloids from Echium rauwolfii and Echium horridum (Boraginaceae). $\mathrm{Z}$. Naturforsch. 54c, 295-300. 